\title{
Consumer Credit Law and the Protection of Low-income Consumers in the United Kingdom
}

\author{
Ticen Azize Özraşit \\ Rauf Denktaş University, Lefkoşa, KKTC \\ E-mail : ticen.ozrasit@rdu.edu.tr
}

\begin{abstract}
Since the mid -1980's consumer credit has grown rapidly in most European countries. Consumer credit is of great importance in our lifestyle model of consumption. Consumer credit plays an important role in lifecycle budgeting, balancing saving, spending and income smoothing". Consumer credit furthermore "permits the accumulation of capital assets". However, one cannot deny that whether consumer credit is used for the accumulation of capital assets (such as housing), depreciating assets or expensive external services, low - income consumers are nevertheless the most vulnerable against the use of credit. This is because nearly two-thirds of low-income households have no savings and of those who do save, have insufficient money that precludes the need for borrowing
\end{abstract}

Keywords: Consumer Credit, Low-Income, Protection, United Kingdom

DOI: $10.7176 / \mathrm{JLPG} / 118-03$

Publication date: February $28^{\text {th }} 2022$

\section{Introduction}

Low-income consumers are among the most vulnerable in the credit market, especially against illegal moneylenders. Loan sharks are known to primarily attack areas of poverty, especially single mothers in receipt of benefits or people with mental health issues. Studies have shown that approximately 165,000 households in the United Kingdom are using illegal moneylenders each year. There have in response to this, been illegal moneylending projects to increase awareness of the problems of illegal lending and to create a climate where the victims can step forward ${ }^{1}$. Furthermore, during the parliamentary passage of the Consumer Credit Act 2006, there have been calls to introduce ceilings. For many years there have been debates about high cost credit and the UK government has been under pressure to act against extortionate credit. Therefore, it is worth an attempt to incorporate a methodology on low-income consumers and how they can be protected against abuses in the credit market.

\section{The Protection of Low- Income Consumers}

It is often believed that poor consumers have a higher risk of default, which justifies higher interest rates. It has been argued that, the social security system hurts the poor in numerous ways. According to Friedman, the poor pay relatively more for their benefits; the poor pay several more social security taxes for several more years, the poor pay more because there is a lower tax rate for self-employed than employed workers and because the poor pay more for less. Caplovitz also argued that unlike middle-class consumers, the poor are unable to avail themselves of the traditional sources of consumer credit, whether it was the result of insufficient income, educational deficiency or job instability ${ }^{2}$. Borrowing became the need to ease the ongoing pressure of income inadequacy, and this has made low income consumers the focal point for consumer protection. Several researches have shown that consumers are the most vulnerable in the market. The Federal Trade Commission has in relation to low income households, researched the prices of consumer durables such as television sets, freezers, washing machines and dryers. According to the Federal Trade Commission, consumers purchasing from lowincome market retailers were paying higher prices than general market retailers. Similarly, studies have shown that payday loans are used by 8 per cent of low-incomes credit users and the leading source of credit for those on low incomes, are used by 41 per cent and 37 per cent of low-income credit users respectively ${ }^{3}$.

Recommendations have however been made to solve the matter of making the 'poor not poor'. These include: Policy approaches to consumer protection and credit market regulation, arguing the need to work with the reality of life on a low income, recognizing that credit use will always be a feature of the financial management of those on low incomes, and focusing on how most effectively to make credit markets best fit with their needs, while minimizing the potential for detriment ${ }^{4}$.

\footnotetext{
${ }^{1}$ Ian Ramsey, (2012) “Consumer Law Policy, 3rd edition, Hart Publishing”, 66-78

${ }^{2}$ David Caplovitz, (1967), "The poor pay more: consumer practices of low-income families" Free Press.

${ }^{3}$ Peter Cartwright, (1999), "Consumer Protection in Financial Services" Kluwer Law International.

${ }^{4}$ Cayne, D \& Trebilcock's, M, (1793) "Market Considerations in the Formulation of Consumer Protection Policy" The University of Toronto Law Journal, Vol 23, No. 4, 396 - 430.
} 


\subsection{Interest Rate Celling's}

The UK government have not introduced interest rate ceilings, as in their view it would distort the market. As There are however several rationales for ceilings, including; ensuring a fair price in transactions, preventing externalities from high cost credit and responding to behavioral mistakes where individuals are perceived to underestimate the risks of high cost credit. In contrast, however, interest rate ceilings are also seen has a blunt instrument as the Office of Fair Trading in response to the DTI's consultation document in 2003 noted: "We agree with DTI that interest rate ceilings could be problematic and may be counter-productive. Any system of regulating interest rates in the UK would require a multiplicity of ceilings or thresholds, given the complexity of the credit market. There is a clear danger that such an approach may distort the market or competition within it." It is therefore believed that a form of high cost low income lending, is more suited to the needs of lowincome consumers in the United Kingdom.

Anna Ellison and Robert Forster, in relation to interest rate ceilings have conducted a study, including countries such as France, Germany, Australia and the UK, primarily because these countries are among the largest and important credit markets. According to these studies: Illegal lending is much higher in the ratecapped markets of France and Germany than in the UK, where there is no ceiling. Moreover, the primary explanation for the more rapid growth in the credit market in Australia and the UK than in France and Germany lies with the absence until now of an effective interest rate ceiling in those markets. ${ }^{2}$ The study concluded that a rate ceiling would not necessarily reduce the cost of credit for low-income borrowers and a rate ceiling would appear unlikely to prevent over-indebtedness. It is more likely to increase the indebtedness of low-income borrowers and to simply shift more debt into revolving credit vehicles being repaid over extended terms. The study conducted by Anna Ellison and Robert Forster, suggests that interest rate ceilings do not protect lowincome consumers. It seems to me, although each country whether Australia, France, Germany or the United Kingdom have their own distinct preferences on whether they choose to oppose or support interest rate ceilings, a rate ceiling would appear unlikely to prevent over-indebtedness. ${ }^{3}$ The existence or the absence of a rate ceiling in the United Kingdom would probably have made no difference for a low-income consumer. Consumer credit law however is not limited to interest rate ceilings, there are other instruments that have the effect of providing protection for lower income consumers.

\subsection{High Cost Credit and Irresponsible Lending}

In June 2004, The National Consumer Council had asked the Office of Fair Trading to look at concerns in the home credit sector. The National Consumer Council was concerned that there were competitive failings in the market for home credit. The National Consumer Council was further concerned with high market concentration which may reduce consumer choice and high prices. The Office of Fair Trading's response noted that many home credit consumers were in a poor bargaining position and consumers were finding it difficult to compare loans. This super complaint, led to a Competition Commission investigation of the high cost credit market. The Competition Commission also introduced what they called the remedy package, which comprised four remedies: (a) data sharing; to reduce the information advantages enjoyed by incumbent lenders over other actual or potential lenders; (b) price information; to provide pricing information about their home credit products on request, either orally or in writing, to the customer within one week of a request, (c) statements; used as a conduit for information and (d) changes to early settlement rebates: to increase price transparency.

The Competition Commission also reviewed but rejected a price cap remedy as it would limit price competition and risk the access of credit to riskier consumers. Furthermore as, Professor Iain Ramsey argued "celling's might prevent welfare opportunism among groups living a 'live now pay later' lifestyle." Perhaps, we can make some sense from David Cayne and Michael Trebilcock's argument that competition protects the lowincome consumer in the credit market because it is a way of ensuring that excessive profits are not made. Furthermore, in 2009 the Office of Fair Trading proposed a study on whether high cost credit was working well for consumers. The Office of Fair Trading found that problems arose from deep-seated issues such as the financial capacity of consumers. Moreover, having considered price controls the Office of Fair Trading concluded that high cost credit is by nature expensive, which derives from the low value of the loan and incidence of missed or late payments ${ }^{4}$. In response to these concerns, the Office of Fair-Trading notes that the high credit sector in the UK is working considerably well but some improvements are recommended ${ }^{5}$.

In the OFT's view the Government should consider the case for introducing legislation to create a single website allowing consumers to compare the features of home credit, payday and pawn broking loans alongside

\footnotetext{
${ }^{1}$ Office of Fair Trading (2011) Irresponsible Lending: OFT Guidance for Creditors, London: Office of Fair Trading.

${ }^{2}$ Ellison, A., Whiley, C, Forster, R Paul A. \& Jones, P (2011) "Credit and low-income consumers: a demand-side perspective on the issues for Consumer protection" Friends Provident Foundation, p.108.

${ }^{3}$ Ibid... p.108

${ }^{4}$ Office of Fair Trading (2011) Irresponsible Lending: OFT Guidance for Creditors, London: Office of Fair Trading.

${ }^{5}$ Collard, S. and Kempson, E. (2005) “Affordable Credit: The Way Forward”, Bristol: Policy Press.
} 
credit unions and other lenders in their local area. Furthermore, the need to be more effort in promoting best practices and codes of practice against high cost credit suppliers. These recommendations made by the Office of Fair Trading is intended to assist the government in considering its approach to the challenging high-cost credit sector. In 2011, the Office of Fair Trading targeted the issue of irresponsible lending and noted that "borrowers who may be particularly vulnerable virtue of their poor credit history, current indebtedness or by any reason of age and health should in particular not be targeted or exploited." The Office of Fair Trading also recommends what they call the assessment of affordability. The Office of Fair Trading defines this test as a 'borrower-focused test' which involves a creditor assessing a borrower's ability to undertake a specific credit commitment, or specific additional credit commitment, in a sustainable manner, without the borrower incurring (further) financial difficulties and/or experiencing adverse consequences ${ }^{1}$.

In the OFT's view any assessment of affordability, should be dependent upon- and proportionate to- a number of factors - which may include; the type of credit product, the borrowers financial situation at the time the credit is sought, the borrowers credit history, and the amount of credit to be provided, the vulnerability of the borrower, the impact of a future change in the borrower's personal circumstances and the associated cost and risk to the borrower. The assessment of affordability, may demonstrate that the borrower cannot meet repayments of the credit agreement, in such situation the OFT recommends that a smaller amount of credit may be considered suitable for the borrower.

\subsection{Bill of Sale Lending}

In 2009, the government introduced a consultation paper named 'A Better Deal for Consumers Delivering Real Help Now and Change for the Future' that was a proposal to ban the use of bills of sale for consumer lending. A bill of sale is a form of consumer lending and is used to secure a loan on an item of personal property owned by the consumer. However, the government considered that proposals to ban bill of sale lending would have resulted in job losses and would have also meant that low-income consumers would have no access to credit ${ }^{2}$. Furthermore, it would be disproportionate to ban an entire industry for the actions of a few rogue lenders and a ban would restrict consumer access to credit, thus reducing choice, pushing up prices, and potentially forcing some consumers into the hands of illegal lenders. The government found that the only way to tackle this issue is; a code of practice that contains increased protections for consumers, especially for those who are having difficulty repaying the loan and a consumer information sheet explaining in plain English how bills of sale.

\subsection{Consumer Credit Law}

The Consumer Credit Act 1974 introduces a new protection for consumers and is capable of providing protection against 'ghetto merchants, slum landlords and loan sharks. This is because the 1974 Act requires a full license by the Office of Fair Trading. Section 39 of the act notes that without a legal license a trade between the buyer and seller is deemed to be illegal. Furthermore, s40 notes that a license cannot be enforced without the leave of the Office of Fair Trading ${ }^{3}$.

Required disclosers are also a central part of the Consumer Credit Act 1974. Under section 44 of the act, advertisements are required to convey a fair and reasonable indication of the nature of the credit. Furthermore, section 60 notes that a debtor should be made aware of the rights and duties imposed on him by the agreement, the amount and rate of the total charge for credit and the protection and remedies available to him. As Professor Iain Ramsay notes, there are various reasons why credit disclosures are effective. These include: performing a market perfecting function by proving a low-cost reliable signal for individuals and disclosures perform a warning function, altering a consumer to particularly high cost of credit. Furthermore, the Consumer Credit Act 1974 provides the consumer with the ability to challenge an unfair credit relationship. Under 140A of the Act, the court can alter the terms of a credit agreement, reduce the amount payable to the borrower or refund money to the borrower. The Consumer Credit Act also provides a right to a free dispute resolution via the Financial Ombudsman Service. The unfair relationship test is however a troubling test, there still seems to be the question of where we draw the line in relation to fairness.

\subsection{Income expenditure for mortgage}

The Financial Service Authority in 2010, noted, "Our principal aim is to ensure that consumers take on mortgages that they can afford to repay, and we want to ensure that affordability assessments are robust enough to prevent consumers being foreseeably over-stretched". The FSA noted that "that lenders should fully assess the consumer's ability to repay for all mortgage applications, in the light of their income, expenditure and outstanding debts; assessing borrowing capacity based on the consumer's free disposable income (i.e. income net

\footnotetext{
${ }^{1}$ Office of Fair Trading (2011) Irresponsible Lending: OFT Guidance for Creditors, London: Office of Fair Trading.

2 Policy" The University of Toronto Law Journal, Vol 23, No. 4, 396 - 430

${ }^{3}$ Siciliani, P, Riefa, C \& Gamper, H, (2021), "Consumer Theories of Harm: An Economic Approach to Consumer Law Enforcement and Policy Making” Bloomsbury Academic, 68-122.
} 
of all expenditure), allowing for future increases in interest rates. The lender should lend only where it assesses that the consumer can afford to service the mortgage" 1 .

\section{Solving the Problem}

There is no doubt that the legislative forms of the Consumer Credit Act 1974, makes consumer credit agreements easier to challenge where agreements are found to be unfair. The government is also considering options to provide better information and improved choices for consumers as we have seen by recommendations made by the Office of Fair Trading or Financial Service Authority. In 2014 the Office of Fair Trading had passed its responsibilities to organizations such as Competition and Markets Authority (CMA) and the Financial Conduct Authority (FCA) due to is closure. The OFT's goal was to make markets work well for consumers, ensuring vigorous competition between fair dealing businesses and prohibiting unfair practices such as rogue trading, scams, and cartels ${ }^{2}$. The FCA had in October 2020 put a place of package of support for people in difficulty in which was a reminder to consumers that help was available from lenders if they were finding it hard to keep up with payments due to coronavirus. According to a survey, 12 million people in the United Kingdom had low financial resilience. The FCA could have included low-income consumers in their regulatory outcomes, as lowincome families have yet been left out from consumer protection.

There is little evidence to suggest that low-income consumers are better protected in the credit market. There is also little evidence to show that reforms for fairness and transparency for low-income consumers in the credit market have been achieved. Recommendations such as caps on extortionate interest rates are said to provide greater transparency in the credit market, but perhaps, the best recommendation to protect low-income consumers in the credit market would be to avoid a 'one size fits all' approach. The regulators need to be more aware of the risks not only of those at the margins of the credit market but for those who do not have access to credit. This brings us back to Cayne and Trebilcock's argument "The consumer problems of the poor can only be remedied by making the poor not poor.

\section{Conclusion}

There are no simple explanations or solutions for the challenges that low-income consumers confront in the credit market. Consumer credit law may not fill all the missing gaps to prevent over indebtedness, but it nevertheless has the effect of protecting lower income consumers. There have also been considerable efforts to open access to affordable credit to low income households. Perhaps the only recommendation to make would be that regulators should be more aware of the risks of low-income consumers who have no or very little access to credit, as there has not yet been a stable solution for the consumer problems of the poor. The government should have set out a minimum level of protection especially for low-income families to remain financially stable during Covid-19. The consumer market is therefore failing to protect low income consumers.

\section{References}

Peter Cartwright, (1999), "Consumer Protection in Financial Services” Kluwer Law International.

David Caplovitz, (1967), “The poor pay more: consumer practices of low-income families” Free Press.

Collard, S. and Kempson, E. (2005) "Affordable Credit: The Way Forward”, Bristol: Policy Press.

Cayne, D \& Trebilcock's, M, (1793) "Market Considerations in the Formulation of Consumer Protection Policy" The University of Toronto Law Journal, Vol 23, No. 4, 396 - 430.

Ellison, A., Whiley, C, Forster, R Paul A. \& Jones, P (2011) "Credit and low-income consumers: a demand-side perspective on the issues for Consumer protection" Friends Provident Foundation, 7-108.

Office of Fair Trading (2010) Review of High Cost Credit: Final Report, London: Office of Fair Trading.

Office of Fair Trading (2011) Irresponsible Lending: OFT Guidance for Creditors, London: Office of Fair Trading.

Ian Ramsey (2012) "Consumer Law Policy, 3rd edition, Hart Publishing”, 66-78

Siciliani, P, Riefa, C \& Gamper, H, (2021), "Consumer Theories of Harm: An Economic Approach to Consumer Law Enforcement and Policy Making” Bloomsbury Academic, 68-122.

Winn, J (2007) "Consumer Protection in the Age of the 'Information Economy' Markets and the Law”, Ashgate Publishing, 50

Vandone, D, (2009) "Consumer Credit in Europe” Springer, 23.

\footnotetext{
${ }^{1}$ Office of Fair Trading (2011) Irresponsible Lending: OFT Guidance for Creditors, London: Office of Fair Trading.

${ }^{2}$ Siciliani, P, Riefa, C \& Gamper, H, (2021), "Consumer Theories of Harm: An Economic Approach to Consumer Law Enforcement and Policy Making” Bloomsbury Academic, 68-122.
} 